\title{
Lectotypification of Boschniakia himalaica, the basionym of Xylanche himalaica (Orobanchaceae)
}

\author{
Kumar A. ${ }^{1 *}$ \& O.N. Maurya ${ }^{2}$ \\ ${ }^{1}$ Central National Herbarium, Botanical Survey of India, P.O. Botanic Garden, Howrah, West Bengal - 711 103, India. \\ Botanical Survey of India, CGO Complex, Salt Lake City, Kolkata, West Bengal - 700 064, India. \\ *E-mail: anand_kum234@rediffmail.com
}

\begin{abstract}
A lectotype is designated here for the name Boschniakia himalaica Hook.f. \& Thomson, the basionym of Xylanche himalaica (Hook.f. \& Thomson) Beck.
\end{abstract}

Keywords: Boschniakia himalaica, Lectotype.

\section{Introduction}

Beck (1890) described the genus Xylanche Beck based on Boschniakia himalaica Hook.f. \& Thomson which was segregated from Boschniakia C.A.Mey. ex Bong. in having tricarpellate pistils. Phylogenetic evidence (Wolfe et al., 2005; Bennett \& Mathews, 2006; Park et al., 2008) also supported segregation of Xylanche from Boschniakia. However, the molecular work by McNeal et al. (2013) did not support segregation of Xylanche and they used B. himalaica and B. rossica (Cham. \& Schltdl.) B.Fedtsch. under genus Boschniakia. However, Piwowarczyk (2015) carried out seed morphological studies of Boschniakia s.l. which supported a segregation of Xylanche from Boschniakia.

$X$ lanche is represented by the sole species $X$. himalaica (Hook.f. \& Thomson) Beck distributed mostly in temperate and subalpine Himalayas, to altitudes over $4000 \mathrm{~m}$ (Nepal, Bhutan, India, and China) with disjunct distribution in Taiwan (Piwowarczyk, 2015). In India, the species is

Received: 10.12.2019; Revised \& Accepted: 01.09.2020 Published Online: 30.09.2020 restricted to Arunachal Pradesh, Meghalaya, Sikkim and Uttarakhand (Anilkumar, 2000).

While working on the genus Boschniakia for the Flora of India, the authors found that the name Boschniakia himalaica Hook.f. \& Thomson appears to be as yet untypified (Smith, 1933; Zhang, 1987; Anilkumar, 2000; Yu, 2013; Collins et al., 2019). After critical studies of type specimens and comparison with the protologue, a lectotypification is presented here in accordance with the Art. 7.11 of the Shenzhen Code (Turland et al., 2018).

\section{Typification}

Boschniakia himalaica Hook.f. \& Thomson in Hook.f., Fl. Brit. India 4: 327.1884 (= Xylanche himalaica (Hook.f. \& Thomson) Beck, Biblioth. Bot. 4(19): 58. 1890). Lectotype (designated here): INDIA, Sikkim, Lachen valley, $12000 \mathrm{ft}$., associated with roots of Rhododendron sp., s.d., J.D. Hooker s.n. (K [K000938934 digital image!]). Residual syntypes: INDIA, Sikkim, 10-12000 ft., s.d., J.D. Hooker s.n. (CAL [CAL0000019107!, CAL0000019108!], E [E00273644 digital image!], GH [GH00914299 digital image!], K [K000938933 digital image!], M [M0185512 digital image!], MPU [MPU021194 digital image!], P [P02968827, P02968828 digital images!], S [S11-7045 digital images!]); Singaleleh [Singalila], $12000 \mathrm{ft}$., "on roots of Rhododendron”, 08.10.1870, C.B. Clarke 13424 (CAL [CAL0000019106!]); Jongri, 13000 ft., 15.10.1875, C.B. Clarke 25743 (K [K001392680 digital image!]); C.B. Clarke 25812 (K [K001392681 digital image!]). Uttarakhand, Kumaon, Dwali, 
8300 ft., R. Strachey \& J.E. Winterbottom 2 (GH [GH00914298 digital image!], K [K001392697 digital image!]).

Fig. 1

Notes: Hooker and Thomson (1884) described Boschniakia himalaica based on the collections of J.D. Hooker and C.B. Clarke from Sikkim and R. Strachey \& J.E. Winterbottom from Garhwal and Kumaon. We traced a total of 14 herbarium sheets (four at $\mathrm{K}$, three at CAL, two at $\mathrm{P}$ and one each at $\mathrm{E}, \mathrm{GH}, \mathrm{M}, \mathrm{MPU}$ and S). At $\mathrm{K}$ one sheet is a mixed collection, with the right-most specimen representing a J.D. Hooker collection (K000938933), while the other five specimens belong to R. Strachey \& J.E. Winterbottom collection (K001392697). The sheet K000938934 bears flowering and fruiting fragments, a label with the name "Boschniakia himalaica" and altitude "1012000 ped", and a second label with the annotation "Rhododendron roots", "Lachen valley”, "12000 ft.", all in Hooker's handwriting. Moreover, it also bears

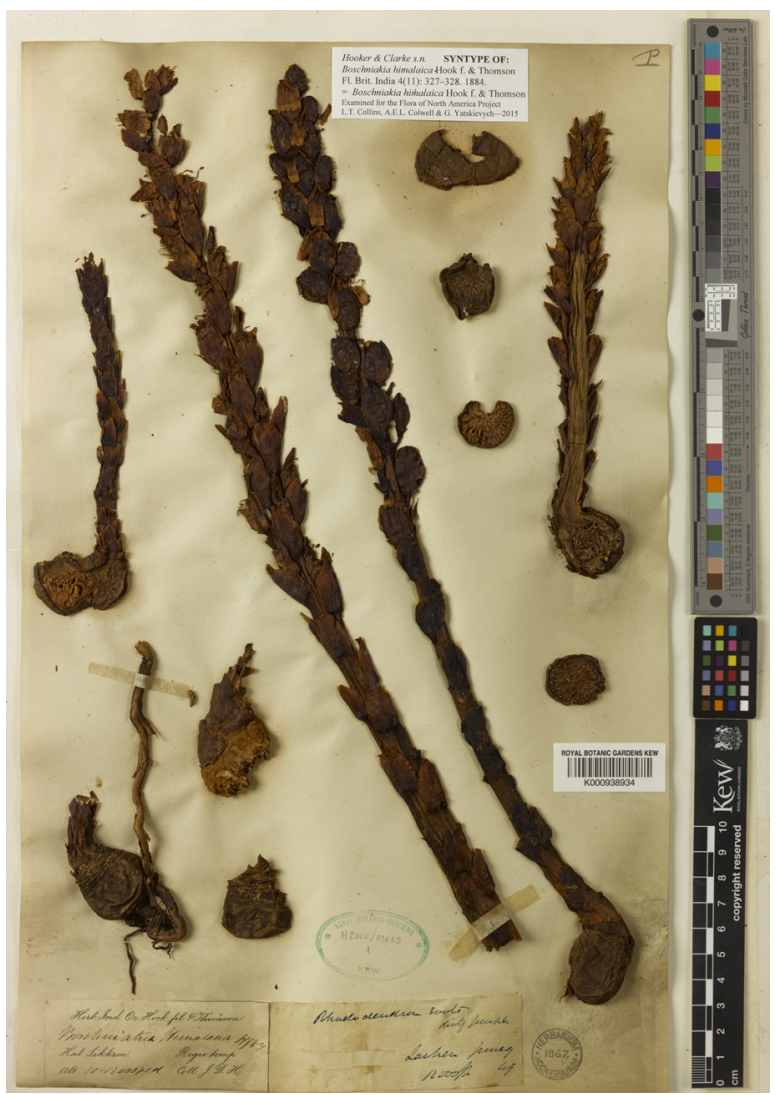

Fig. 1. Lectotype of Boschniakia himalaica (K000938934). (C) The Board of Trustees of the Royal Botanic Gardens, Kew. http:// specimens.kew.org/herbarium/K000938934 an annotation of Collins et al. in 2015 as syntype for the Flora of North America Project, but this species was not treated by Collins et al. (2019) in the Flora of North America. All the remaining sheets collected by Hooker at CAL, E, M, MPU, P and S bear Hooker's collection label with the name "Boschniakia himalaica" and altitude "10-12000 ped" in Hooker's handwriting. The sheet CAL0000019106 collected by C.B. Clarke from "Synglelah, Sikkim" at an altitude of $12000 \mathrm{ft}$. is in brittle condition and devoid of flowers and fruits. There are two sheets of C.B. Clarke collected from Jongri at K of which the sheet K001392680 bears drawings with notes in Clarke's handwriting, and the sheet K001392681 bears the annotation "A genus of Hooker \& Thomson grows on roots of Rhododendron" in Clarke's handwriting. Both sheets are without any annotation by Hooker. Thus, the well preserved specimen on sheet K000938934 bearing Hooker's annotation is selected here as lectotype.

\section{Acknowledgements}

Authors are grateful to Dr. A.A. Mao, Director, Botanical Survey of India (BSI), Kolkata and Dr. V.P. Prasad, Head of Office, Central National Herbarium, BSI, Howrah for the facilities; to the Director/Curators of K, P, E, GH, M, MPU, S and JSTOR Plant Sciences for putting the image of the type specimens online; Dr. McNeill (E) for his valuable comments and anonymous reviewers for improvement of the manuscript.

\section{Literature Cited}

ANILKUMAR R. 2000. A taxonomic revision of the family Orobanchaceae in India. Ph.D. thesis, Bharathiar University, Coimbatore.

BECK G. 1890. Monographie der Gattung Orobanche. Bibliotheca Botanica 4(19): 1-275.

BENNETT J.R. \& S. MATHEWS 2006. Phylogeny of the parasitic plant family Orobanchaceae inferred from phytochrome A. American Journal of Botany 93: 10391051. http://dx.doi.org/10.3732/ajb.93.7.1039

COLLINS L.T., COLWELL A.E.L. \& G. YATSKIEVYCH 2019. Boschniakia C.A.Meyer ex Bongard. In: FLORA 
OF NORTH AMERICA EDITORIAL COMMITTEE (eds.), Flora of North America: Magnoliophyta: Tetrachondraceae to Orobanchaceae. Volume 17. Oxford University Press, New York.

HOOKER J.D. \& T. THOMSON 1884. BoschniakiaC.A.Meyer ex Bongard. In: HOOKER J.D. (ed.), The Flora of British India. Volume 4. L. Reeve \& Co., London. pp. 327-328.

McNEAL J.R., BENNETT J.R., WOLFE A.D. \& S. MATHEWS 2013. Phylogeny and origins of holoparasitism in Orobanchaceae. American Journal of Botany 100: 971-983. http://dx.doi.org/10.3732/ ajb.1200448

PARK J.M., MANEN J.F., COLWELL A.E. \& G.M. SCHNEEWEISS 2008. A plastid gene phylogeny of the non-photosynthetic parasitic Orobanche (Orobanchaceae) and related genera. Journal of Plant Research 121: 365-376. http://dx.doi.org/10.1007/ s10265-008-0169-5

PIWOWARCZYK R. 2015. Seed morphology of Boschniakia sensu lato (Orobanchaceae) and its taxonomical implications. Phytotaxa 231(2): 156-164. https://doi.org/10.11646/phytotaxa.231.2.4
SMITH H. 1933. Plantae Sinenses: XXVI. Orobanchaceae. Acta Horti Gothoburgensis 8: 127-146.

TURLAND N.J., WIERSEMA J.H., BARRIE F.R., GREUTER W., HAWKSWORTH D.L., HERENDEEN P.S., KNAPP S., KUSBER W.-H., LI D.-Z., MARHOLD K., MAY T.W., MCNEILL J., MONRO A.M., PRADO J., PRICE M.J. \& G.F. SMITH (eds.) 2018. International Code of Nomenclature for algae, fungi, and plants (Shenzhen Code) adopted by the Nineteenth International Botanical Congress Shenzhen, China, July 2017. Regnum Vegetabile 159.Koeltz Botanical Books, Glashütten. https://doi.org/10.12705/ Code. 2018

WOLFE A., RANDLE C., LIU L. \& K. STEINER 2005. Phylogeny and biogeography of Orobanchaceae. Folia Geobotanica 40: 115-134. http://dx.doi.org/10.1007/ BF02803229

YU W.B. 2013. Nomenclatural clarifications for names in Boschniakia, Kopsiopsis and Xylanche (Orobanchaceae). Phytotaxa 77 (3): 40-42. http://dx.doi.org/10.11646/ phytotaxa.77.3.1

ZHANG Z. 1987. A taxonomic study of the genus Boschniakia (Orobanchaceae). Acta Botanica Yunnanica 9: 289-296. 